\title{
Squamous odontogenic tumor-an exceptionally rare neoplasm
}

\author{
Dr. Munmun Nahar ${ }^{1 *}$, Dr. Mohammad Asifur Rahman², Dr. Md. Abdul Hannan³ ${ }^{3}$ Dr. Ismat Ara Haider ${ }^{4}$
}

\section{AFFILIATION:}

1. Dr. Munmun Nahar, BDS, MS (OMS) Thesis Part, Department of Oral and Maxillofacial Surgery, Dhaka Dental College \&Hospital, Dhaka.

2. Dr. Mohammad Asifur Rahman, BDS, MS (OMS) Assistant Professor, Department of Oral and Maxillofacial Surgery, Dhaka Dental College\& Hospital, Dhaka.

3. Dr. Md. Abdul Hannan,BDS, MS (OMS)

Assistant registrar,Department of Oral and Maxillofacial Surgery, Dhaka Dental College \& Hospital, Dhaka.

4. Dr. Ismat Ara Haider, BDS, DDS, MS(OMS)

Professor \& Head, Department of Oral and Maxillofacial Surgery, Dhaka Dental College \& Hospital, Dhaka.

\section{Article info.}

Received: $15^{\text {th }}$ April, 2018

Accepted: $17^{\text {th }}$ June, 2019

Volume: 9, Issue-2 October, 2019

DOI: $\underline{\text { https://doi.org/10.3329/updcj.v9i2.43740 }}$

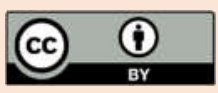

(C) Authors retain copyright and grant the journal right of first publication with the work simultaneously licensed under Creative Commons Attribution License CC - BY 4.0 that allows others to share the work with an acknowledgment of the work's authorship and initial publication in this journal.

https://creativecommons.org/licenses/by/4.0/

Publisher: Update Dental College, Dhaka, Bangladesh

Web: www.updatedentalcollege.edu.bd

E-mail: updcj@hotmail.com

\author{
* Corresponding Author \\ Dr. Munmun Nahar \\ BDS, MS(OMS)Thesis Part, \\ Department of Oral and Maxillofacial Surgery, \\ Dhaka Dental College Hospital, Dhaka. \\ Email:mnsurovi@gmail.com \\ Cell: +8801719883488
}

\section{Citation}

Dr. Munmun Nahar, Dr. Mohammad Asifur Rahman, Dr. Md. Abdul Hannan, Dr. Ismat Ara Haider, Squamous odontogenic tumor-an exceptionally rare neoplasm. Update Dental College Journal. 2019 October; 9(2):43-45 DOI: https://doi.org/10.3329/updcj.v9i2.43740

\begin{abstract}
The squamous odontogenic tumor (SOT) is exceptionally rare, benign, locally infiltrative neoplasm of the jaws originating from the rests of Malassez, gingival surface epithelium or from remnants of the dental lamina which is asymptomatic in nature, may present with symptoms of pain and tooth mobility. Radiographic appearance shows a triangular-shaped unilocular radiolucency associated with the roots of erupted, vital teeth. Common site of this tumor is anterior maxilla and the posterior mandible. Histologically, the formation of variable sized nests and cords of uniform, benign-appearing, squamous epithelium with occasional characterize the tumor Vacuolization and keratinization. Here we will present a case of squamous odontogenic tumor (SOT) occurring in a12 years-old female in the left side of upper jaw.
\end{abstract}

\section{KEY WORDS:}

Squamous Odontogenic Tumor, Rests of Malassez, Squamous cells

\section{INTRODUCTION:}

Squamous odontogenic tumor is a benign lesion. It is developed from a neoplastic change of epithelial rests of Malassez. ${ }^{1}$ Its histologic features misguided as an acanthomatous ameloblastoma or as a desmoplastic ameloblastoma. ${ }^{2}$ There are few cases have been published till now in literature, here we present a case of squamous odontogenic tumor arising in the posterior portion of maxilla which is its unusual site.

\section{CASE REPORT}

A 12-years-old male child patient reported to our dental hospital with the chief complaint of swelling in the left upper jaw for 12 months, which was asymptomatic. The swelling was rapidly increasing in size for last 2 months. The patient was moderately nourished with an unremarkable medical history. Clinical examination revealed a firm swelling in left maxilla extending from left lateral incisor to left $1^{\text {st }}$ molar region. The maxillary left lateral incisor and 1 st and $2^{\text {nd }}$ premolar were mobile (fig 1 \&2)
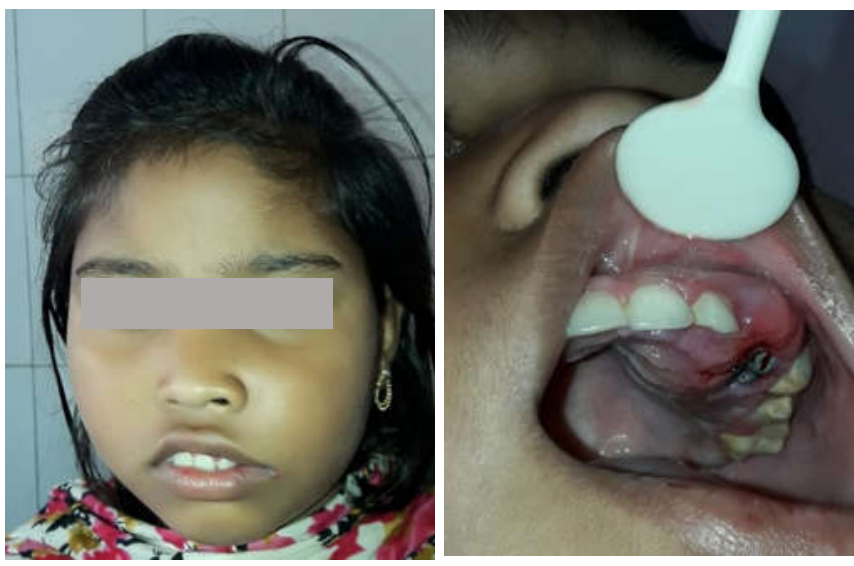

Fig 1: Extra oral sweeling on left maxilla, Fig 2: Intra oral examination 


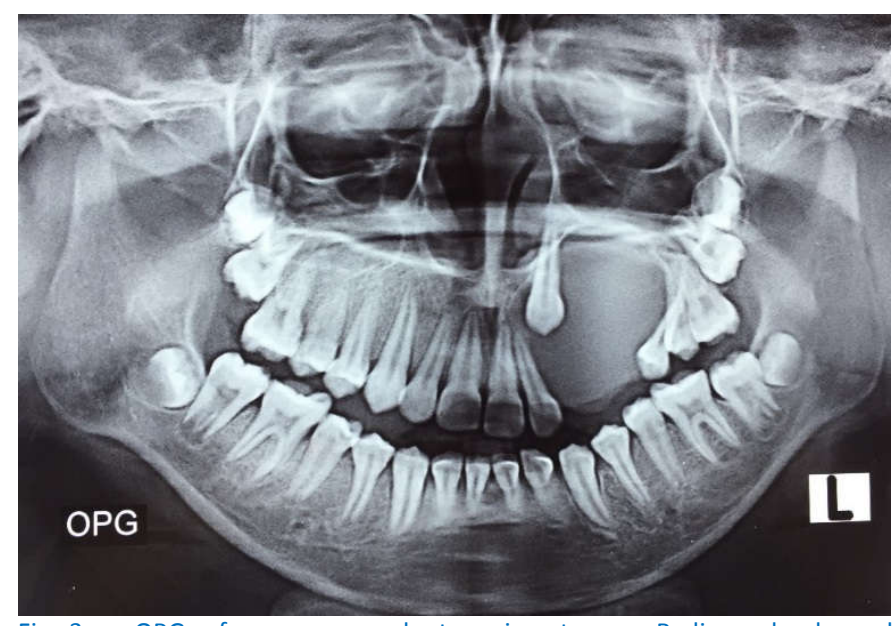

Fig 3 - OPG of squamous odontogenic tumor, Radiograph showed radiolucency with severe alveolar bone loss localized between left lateral incisor and $1^{\text {st }}$ premolar region of left maxilla.

Investigation reports showed Heamoglobin 13.6\%,Total lymphocyte count-14,200/cu mm, differential lymphocyte count , Neutrophil-61\%, Lymphocyte-32\%, Eosinophil07\%, and other vital parameters were within normal limits. Based on the clinical and radiographic findings patient was subjected for incisional biopsy. Histological examination pieces of mucosa represent squamous epithelium. The underlying fibrous stroma contains islands of well differentiated squamous epithelium, cells show focal cystic degeneration with no atypia or mitosis. Diagnosis of squamous odontogenic tumor was confirmed. Then we have planned for excisional biopsy under general anaesthesia .With all available aseptic precaution intraoral crevicular incision given extending from left central incisor to left $1^{\text {st }}$ molar area(fig $4 \& 5$ ).
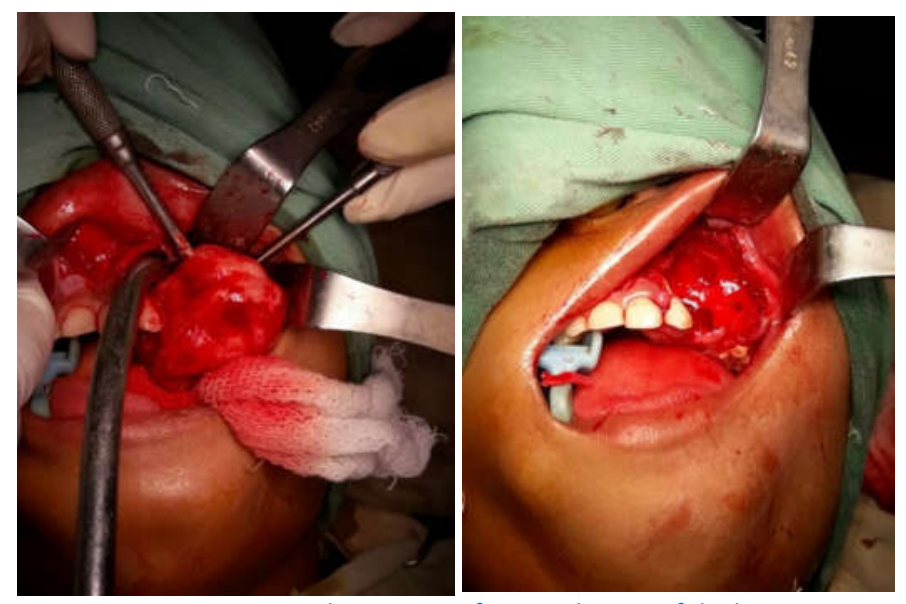

Fig 4 - Per operative procedure.Fig 5 - After enucleation of the lesion

Mucoperiosteal flap is raised. The lesion enucleated intact leaving a bony cavity of about $2 \times 3 \mathrm{~cm}$. The cystic lining was sent for histo-pathological examination. (fig 6) Received specimen measures about $3.0 \mathrm{~cm} \times 2.0 \mathrm{~cm} \times 1.0 \mathrm{~cm}$, irregular shaped and soft with lobulated cut surface. Histopathological examination of the lesion showed squamous cells are irregular shaped in the form of islands, clusters, trabeculae and strands

44 | P a g e lined by abundant collagenous stroma. Thus overall features had similarity with squamous odontogenic tumor. $1^{\text {st }}$ followup: one month later: Swelling over left side of maxilla was reduced. Wound margin was healthy.(fig7) $2^{\text {nd }}$ follow-up: two month later: Swelling was reduced markedly with good oral hygiene.(fig8)
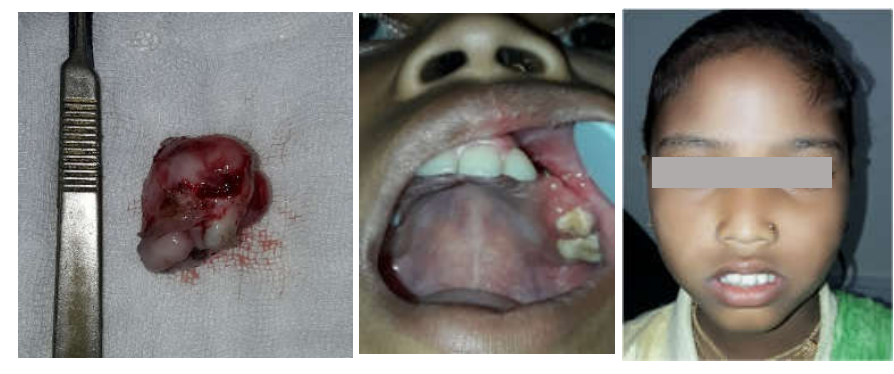

fig 6 - The intact lesion, Fig 7 - follow up period , Fig 8 - Follow up period

\section{DISCUSSION}

Squamous odontogenic tumor is a benign lesion with rare incidence. Pullon et al.[1] were described it at first. They reported six cases and established diagnostic criteria and surgical approaches that are still followed today.Very few cases have been located within the bone, although a few peripheral cases have been discussed. Before 1975, this lesion was misguided as atypical acanthomatous ameloblastoma or even a squamous cell carcinoma. Peak incidence of Squamous odontogenic tumors in patients ages ranged from 8 to 74 years (average age 38). The mandible or the maxilla occurrence of the lesion is same. Males and female ratio 1:1. [2]

Histological appearance of squamous odontogenic tumor may be is diversified. The source of the lesions which developed in association with the crown of unerupted or impacted tooth are the Rests of Malassez. Epithelium is lined by stratified squamous epithelium. Those lesions which are extraosseous originated from rests of Serres. [3]

Lesions of maxilla normally occur in the anterior regions, while mandibular cases are more often found in the posterior areas. Maxillary lesions are seem to grow more aggressively. [4] Squamous odontogenic tumor's clinical and radiographic features may be confused with a number of other pathologies. Patients with this lesion may present with an progressive swelling of the maxilla or mandible, mobile tooth, soft tissue ulceration, pain, and displaced tooth .Our described lesion, revealed a typical pattern of squamous odontogenic tumor in most parts. Thus, the most appropriate interpretation for this lesion as squamous odontogenic tumor was made. Squamous odontogenic tumors have some locally invasive potential and rarely recur after conservative therapy. Curettage or excision is the treatment of choice [5]

Histopathology reveals islands of proliferative squamous epithelium uniformly distributed in a connective tissue stroma. The islands are easily recognized.A flattened layer of cells separating this islands from the surrounding stroma at their periphery. The epithelium in these rounded islands often shows a swirling or"whirlpool" pattern . Cystic degeneration Website: https://www.banglajol.info/index.php/UpDCJ 
occurs centrally within the epithelial islands which denotes keratinization of the central cells[6]. Diagnosis is confirmed by histopathologic features. Occasionally it is misdiagnosed as peripheral ameloblastoma . [7]

\section{CONCLUSION}

Squamous odontogenic tumor is a benign odontogenic neoplasm of distinctive histological features probably arising from Rests of Malassez, although three decades have passed since the establishment of the lesion as a separate entity much remains to be learned about the squamous odontogenic tumor.

\section{RFFERENCES:}

1.Pullon PA, Shafer WG, Elzay RP. Squamousodontogenic tumor. Report of six cases of a previously undescribed lesion. Oral Surg Oral Med Oral Pathol.1975; 40(5):61730. https://doi.org/10.1016/0030-4220(75)90372-2

2. Neville and Damn, Saunders, Oral and Maxillofacial Pathology, 2nd edition,625-626

3. Squamous odontogenic tumor: Review of literature and a new case; The Journal of Laryngology \& Otology (1985), 99: 919 -924

https://doi.org/10.1017/S0022215100097930

PMid:4045313

4. Olivera,Carrard, Danesi; Rev Cierc. Squamous odontogenic tumor: with recurrence and 12 years follow up; Med., Campinas; 2007 Jan/fev, 16(1); 51- 56,

5. Regezi, Sciubba, Jordan; Saunders (Elsevier); Oral Pathology, Clinical Pathologic Correlations; 277

6. King Kim, Sheldon M. Mintz, Jeffrey Stevens. Squamous odontogenic tumor causing erosion of the lingual cortical plate in the mandible: a report of 2 cases. J Oral MaxillofacSurg2007;65:1227-31.

https://doi.org/10.1016/i.joms.2006.05.051

PMid:17517311

7.Barrios Tomas J., Sudol Jonathan C., Cleveland Deborah B. Squamous odontogenic tumor associated with an erupting maxillary canine: case report. Oral MaxillofacSurg2004;62:742-4.

https://doi.org/10.1016/j.joms.2003.12.014

PMid:15170290 